\title{
EVALUASI “THE RULE OF HALVES" KASUS HIPERTENSI PADA RESPONDEN DI DELAPAN DUSUN BAGIAN SELATAN SLEMAN YOGYAKARTA
}

\author{
Rita Suhadi, Greta Paulina, Yovica Sagina, Chatarina Danik Wijayanti, \\ Lusia S. Dewi, Antonia Adeleide Anutopi, Fransisca Z.Tielman \\ Fakultas Farmasi Universitas Sanata Dharma
}

Korespondensi: ritasuhadi@usd.ac.id

\begin{abstract}
ABSTRAK
Pendahuluan: Prevalensi (50\%), kesadaran (25\%), terapi (12,5\%), dan pengendalian $(6,25 \%)$ hipertensi ditemukan pada populasi berdasarkan the rule of halves (the rule). Penelitian ini bertujuan untuk membandingkan proporsi subyek hasil penelitian dengan yang ada pada the rule.

Metode: Survei analitik cross-sectional dilakukan dengan cluster randomsampling pada 8 dusun di bagian selatan Kabupaten Sleman Yogyakarta. Kriteria inklusi meliputi responden $\geq 40$ tahun dan menandatangani informed-consent; sementara responden yang hamil diekslusi. Data dikumpulkan dengan wawancara dan tekanan darah, berat badan, dan tinggi badan diukur. Perbandingan proporsi subyek dibandingkan the rule dengan uji-Z $(\mathrm{p}<0,05)$; perbandingan umur; body mass index (BMI), dan tekanan darah sistolik/diastolik antara kelompok hipertensi dan tidak hipertensi dianalisis dengan uji-t $\mathrm{p}<0,05$.

Hasil: Subyek (N=1602) memiliki umur 54,3 $\pm 11,8$ tahun; BMI $23,0 \pm 4,2 \mathrm{~kg} / \mathrm{m}^{2}$; dan tekanan darah $141,3 / 83,8 \pm 23,1 / 12,3 \mathrm{mmHg}$. Proporsi subyek berturut-turut terdiri dari 49,3\%; 29,3\%; 19,0\%; dan 3,6\% untuk prevalensi; sadar; terapi; dan pengendalian hipertensi. Subyek memiliki prevalensi yang sama dengan the rule ( $\mathrm{p}>0,05)$; sadar dan terapi hipertensi lebih banyak dibandingkan the rule ( $\mathrm{p}$ $<0,05)$; tetapi pengendalian hipertensi lebih sedikit proporsinya dibandingkan the rule $(\mathrm{p}<0,05)$. Kelompok hipertensi memiliki tekanan darah $(159,0 / 89,8 \mathrm{mmHg})$ berbeda bermakna dengan tidak hipertensi $(124,1 / 78,0 \mathrm{mmHg})$; sama antara yang sadar dan tidak sadar hipertensi; sama antara terima terapi dan tidak terapi; tetapi berbeda bermakna pada kelompok dengan tekanan darah terkendali $(131,3 / 81,4 \mathrm{mmHg})$ dan tidak terkendali $(161,1 / 90,5 \mathrm{mmHg})$.

Kesimpulan: Subyek memiliki prevalensi yang sama; lebih tinggi bermakna untuk sadar dan terapi hipertensi; tetapi lebih rendah untuk pengendalian hipertensi bila dibandingkan the rule of halves.
\end{abstract}

Kata Kunci: Hipertensi, Prevalensi, Sadar-hipertensi, Terapi-hipertensi, Pengendalian Tekanan Darah 


\title{
EVALUATION "THE RULE OF HALVES" HYPERTENSION IN CASE OF RESPONDENTS IN THE EIGHT VILLAGE ON SOUTH PART OF SLEMAN YOGYAKARTA
}

\author{
Rita Suhadi, Greta Paulina, Yovica Sagina, Chatarina Danik Wijayanti, \\ Lusia S. Dewi, Antonia Adeleide Anutopi, Fransisca Z.Tielman \\ Pharmacy Faculty of Sanata Dharma University \\ Correspondence: ritasuhadi@usd.ac.id
}

\begin{abstract}
Background: The prevalence (50\%), awareness (25\%), treatment (12.5\%), and control (6.25\%) of hypertension were found among the population based on the rule of halves (the rule). The study aimed to compare the proportion of subjects found in the study with those in the rule.

Methods: An analytical cross-sectional survey had been done with cluster random-sampling in eight dusuns (villages) in the southern Sleman District of Yogyakarta. The subjects of $\geq 40$ years and signed informed-consent were included; meanwhile pregnant subjects were excluded. Data were collected with interview and measurement of blood pressure level, weight, and height. The proportion of subjects was compared with the rule with $Z$-test $(p<0.05)$; meanwhile the age, body mass index (BMI), and systolic/diastolic blood pressure between hypertensive and not hypertensive groups was analyzed with t-test $(p<0.05)$.

Results: The subjects $(N=1602)$ had the age at $54.3 \pm 11.8$ years; $B M I$ $23.0 \pm 4.2 \mathrm{~kg} / \mathrm{m}^{2}$; and blood pressure $141.3 / 83.8 \pm 23.1 / 12.3 \mathrm{mmHg}$. The subjects comprised 49.3\%; 29.3\%; 19.0\%; and 3.6\% of prevalence; awareness; treament; and controlled hypertension respectively. The subjects had similar hypertension prevalence with the rule ( $p>0.05)$; awareness and treatment hypertension had higher proportion than the rule ( $p<0.05)$; but the well-controlled hypertension subjects had lower proportion than the rule $(p<0.05)$. The blood pressure with $(159.0 / 89.8 \mathrm{mmHg})$ and without $(124.1 / 78.0 \mathrm{mmHg})$ hypertension groups were significantly different; similar between with and without awareness; similar between with and without treatment; but significantly different between controlled $(131.3 / 81.4 \mathrm{mmHg})$ and not-controlled $(161.1 / 90.5 \mathrm{mmHg})$ blood pressure groups.
\end{abstract}

Conclusion: the subjects had the similar prevalence; significantly higher awareness and treatment; but lower control hypertension than the rule of halves. Control

Keywords: Hypertension, Prevalence, Awareness, Treatment, Blood Pressure 


\section{PENDAHULUAN}

Prevalensi hipertensi populasi dewasa di Indonesia berdasarkan Riset Kesehatan Dasar tahun 2007 adalah $31,7 \%-35,8 \% .1$

Kementerian Kesehatan pada tahun 2008 melaporkan hanya $23,9 \%$ dari populasi hipertensi menerima terapi. ${ }^{2}$ Profil prevalensi dan terapi ini menunjukkan tingginya prevalensi tetapi penanganan hipertensi masih rendah pada populasi di Indonesia, padahal hipertensi merupakan penyebab mortalitas dan morbiditas tertinggi terkait penyakit kardiovaskular. ${ }^{3}$

Tekanan darah yang dikendalikan dengan baik dapat mencegah mortalitas dan morbiditas terkait kardiovaskular. Faktor penyebab hipertensi dikategorikan menjadi faktor yang tidak dapat dimodifikasi misalnya umur dan jenis kelamin dan faktor yang dapat dimodifikasi misalnya berat badan, gaya hidup, alkohol, dan merokok. ${ }^{4}$

Umur merupakan faktor hipertensi yang tidak dapat dimodifikasi yang paling dominan dan terkait dengan tekanan darah sistolik atau isolated systolic hypertension. ${ }^{5}$ Merokok > 15 batang per hari menyebabkan permasalahan kesehatan serius. ${ }^{6}$ Faktor pendidikan mempengaruhi hipertensi pada lakilaki sedangkan obesitas dan kurangnya aktivitas fisik pada wanita. ${ }^{7}$ Suatu studi (2003) menemukan pola hidup yang kurang sehat pada populasi di Indonesia sebagai berikut: subyek berumur 10 tahun ke atas yang melakukan latihan fisik $\geq 30$ menit perhari hanya $19 \%$ di perkotaan dan $17 \%$ di pedesaan; laki-laki yang merokok sebesar $40,7 \%$ dan menghabiskan dana $13,2 \%$ untuk rokok. ${ }^{8}$ Riskesdas 2007 hasilnya menunjukkan prevalensi obesitas pada usia $\geq 15$ tahun $13,9 \%$ pada lakilaki dan $23,8 \%$ pada perempuan. ${ }^{2}$
Dalam kasus hipertensi terdapat fenomena the rule of halves (disingkat the rule) atau berarti aturan separuh. Aturan ini diperkenalkan pada tahun 1972. Berdasarkan the rule, hipertensi ditemukan pada $50 \%$ populasi yang diteliti; di antara yang hipertensi hanya 50\% menyadari mengalami penyakit ini; dari yang sadar hipertensi hanya 50\% menerima terapi; dan akhirnya yang menerima terapi hanya 50\% terkendali tekanan darahnya. ${ }^{9}$

Suatu studi di negara maju Belanda ditemukan prevalensi, kesadaran, terapi, dan pengendalian hipertensi berturut-turut 23,3\%; $33,7 \%$; 59,4\%; dan 41,9\%.10 Sebagai pembanding suatu studi di India mewakili negara berkembang dengan jumlah subyek yang lebih sedikit $(\mathrm{n}=$ 1000) ditemukan prevalensi $36,7 \%$; kesadaran 34,6\% dari yang hipertensi; terapi $68,5 \% \quad(\mathrm{n}=87) ;$ dan pengendalian tekanan darah 24,1\% (n $=21) .{ }^{11}$ Pada penelitian di atas proporsi subyek relatif lebih baik dari the rule of halves kecuali untuk pengendalian tekanan darah. Studi lainnya the Jackson Heart Study di Amerika Serikat $(n=5248)$ antara 2194 tahun menunjukkan prevalensi tinggi tetapi dengan tingkat kesadaran, terapi, dan pengendalian tekanan darah yang jauh lebih baik dengan proporsi $62,9 \% ; 87,3 \% ; 83,2 \%$; dan $66,4 \% .{ }^{12}$

Berdasarkan uraian di atas, dilakukan suatu survei yang bertujuan untuk mengetahui prevalensi, kesadaran, terapi, dan pengendalian pada masyarakat Indonesia menggunakan populasi di 8 dusun (padukuhan atau dukuh) bagian selatan Sleman Yogyakarta. Hipotesis studi ini adalah proporsi prevalensi, kesadaran, terapi, dan pengendalian hipertensi tidak berbeda bermakna dengan the rule of halves $(\mathrm{p}$ $>0,05$ dengan uji-Z). 


\section{METODE}

\section{Jenis dan Desain}

Penelitian ini merupakan penelitian observasional dan dirancang dengan desain analitik cross-sectional. Penelitian ini dilakukan di 8 dusun wilayah pedesaan bagian selatan Kabupaten Sleman Yogyakarta.

\section{Seleksi Subyek}

Kriteria subyek adalah pasien berumur lebih dari 40 tahun dan bersedia mengikuti penelitian dengan mengisi informed-consent, sedangkan kriteria ekslusi adalah responden yang hamil dan tidak bisa dilakukan pengukuran tekanan darah, misalnya lengan terlalu besar atau tekanan darah tidak terukur.

\section{Perhitungan Besar Sampel}

The rule of halves memiliki empat tingkatan $(\mathrm{k}=4)$ dari prevalensi sampai dengan pengendalian tekanan darah. Pada tingkatan pengendalian tekanan darah jumlah sampel minimal dihitung dengan rumus (1). ${ }^{13}$ Bila nilai untuk $Z_{\mathrm{a}}=1,96 ; \mathrm{P}$ dan $\mathrm{Q}$ merupakan proporsi responden tekanan darah terkendali dan tidak terkendali sama yaitu 0,5 ; dan d merupakan presisi dengan $\mathrm{d}^{2}=0,01$ diperoleh responden 96 dan dibulatkan menjadi 100 responden. Responden total yang dibutuhkan adalah $100 \times 2^{\mathrm{k}}$ dan bila $\mathrm{k}$ $=4$, maka penelitian memerlukan 1600 responden.

$$
n=\frac{Z \alpha^{2} X P X Q}{d^{2}}
$$

Tempat penelitian meliputi dusun yang dipilih dengan metode non-probability sampling. Setiap dusun dianggap sebagai satu cluster.

\section{Persiapan Penelitian}

Penelitian dimulai dengan permohonan ethical clearance dari Komite Etik, Fakultas Kedokteran Universitas Gadjah Mada Yogyakarta.
Instrumen penelitian berupa Case Report Form (CRF) untuk blangko pengumpulan data, pertanyaan untuk wawancara terstruktur, dan informedconsent diajukan untuk persetujuan komite etik. Timbangan dan meteran yang digunakan telah lulus tara dari Balai Metrologi Yogyakarta, sedangkan sphgymomanometer diuji validitas dibandingkan dengan tensimeter raksa dan diuji reliabilitas menggunakan tiga subyek masing-masing diukur tiga kali. Pertanyaan wawancara diujikan pemahaman bahasa pada tiga orang relawan. Bersamaan dengan ethical clearance dilakukan permohonan ijin dari kantor kecamatan dan kepala dukuh (dusun) masing-masing tempat penelitian.

Tahap berikut adalah penyusunan standar pengukuran tekanan darah. Responden diistirahatkan posisi duduk 10 menit, lalu diukur tekanan darah dua kali dengan interval dua menit, dan tekanan darah yang digunakan sebagai data adalah pengukuran yang kedua. Bila tekanan darah sistolik atau diastolik memiliki selisih lebih dari $10 \mathrm{mmHg}$, dilakukan pengukuran ketiga. Dua dari tiga data yang paling dekat nilainya dirata-rata dan digunakan sebagai data.

\section{Pengumpulan Data}

Data dikumpulkan secara door to door pada periode Juni-Desember 2014. Tekanan darah, tinggi badan, dan berat badan diukur, sedangkan informasi lainnya diperoleh dari wawancara dan disimpan dalam CRF. Data selanjutnya diiput ke dalam worksheet Excel $\mathbb{R}$, dibersihkan, dan disiapkan untuk analisis.

\section{Analisis}

Variabel dalam data kategori terdiri dari jenis kelamin, tingkat pendidikan, merokok, dan latihan fisik. Variabel dalam bentuk data rasio terdiri dari umur, BMI, tekanan darah 
sistolik dan diastolik. Tingkat pendidikan dibagi menjadi dua bagian yaitu S SMP dan > SMP; merokok dibagi menjadi merokok dan tidak merokok tanpa memperhatikan jumlah batang rokok yang digunakan; dan latihan fisik dibagi menjadi latihan fisik $\geq 1$ kali seminggu dan $<1$ kali seminggu. Distribusi responden berdasarkan the rule of halves dan proporsi dalam persentase dihitung dari responden total dan dianalisis secara evaluative (lihat Bagan 1).

Perbandingan rerata data rasio antara kelompok hipertensi (TD $\geq 140 / 90 \mathrm{mmHg}$ ) dan tidak hipertensi dilakukan dengan uji-T yang didahului dengan uji normalitas. Uji normalitas secara deskriptif menggunakan grafik normal Q-Q Plot. Uji-T Uji hipotesis membandingkan proporsi teoritis the rule of halves dengan proporsi hasil survei dilakukan dengan uji-Z ( $\mathrm{p}<0,05)$. Perhitungan uji-Z menggunakan Medcalc suatu program kalkulator on-line. ${ }^{14} \mathrm{H}_{0}$ diterima bila nilai-p $=0,05$ dan $\mathrm{H}_{0}$ ditolak bila nilai-p $\neq 0,05$. Proporsi responden dalam analisis uji-Z dihitung berdasarkan tingkatan the rule of halves sebelumnya misalnya pengendalian tekanan darah dari yang menerima terapi. Proporsi yang sesuai masing-masing tingkatan the rule of halves adalah $50 \%$.

\section{HASIL PENELITIAN}

Responden total penelitian $(\mathrm{N}=$ 1602) diperoleh dari 8 dusun dari 5 kecamatan bagian selatan Kabupaten Sleman. Data populasi di atas > 40tahun disertakan kecuali untuk Kecamatan Wedomartani dalam data gabungan. Penelitian ini mengusahakan mendapatkan seluruh anggota cluster, adanya kendala teknis yaitu responden tidak ada di rumah saya kunjungan pengambilan data atau tidak bersedia mejadi responden, sehingga responden tidak dapat mencakup seluruh populasi. Responden penelitian ini mencapai $48,1 \%$ dari populasi penelitian. (Tabel 1).

Tabel 1. Prevalensi Hipertensi Responden 40 Tahun dan Ke Atas di 8 Dusun di Sleman Yogyakarta Bagian Selatan April 2014-Februari 2015

\begin{tabular}{lccc}
\hline Dusun & $\begin{array}{c}\text { Populasi } \\
\mathbf{4 0} \text { tahun }\end{array}$ & $\begin{array}{c}\text { Responden } \\
\text { (\%) }\end{array}$ & $\begin{array}{c}\text { Prevalensi } \\
\text { (\%) }\end{array}$ \\
\hline Sembir (Prambanan) & 402 & $264(65,7)$ & $40(53,0)$ \\
Jragung (Berbah) & 386 & $244(63,2)$ & $138(56,6)$ \\
Krodan (Depok) & 672 & $239(35,6)$ & $124(51,9)$ \\
Blambangan (Berbah) & 211 & $200(94,8)$ & $98(49,0)$ \\
KadirojoII (Kalasan) & 254 & $200(78,7)$ & $91(45,5)$ \\
Sambisari (Kalasan) & 830 & $200(24,1)$ & $81(40,5)$ \\
Sanggrahan (Wedomartani) & 589 & 137 & $59(43,1)$ \\
Malang Rejo (Wedomartani) & & 118 & $59(50,0)$ \\
TOTAL & 3344 & $1602(48,1)$ & $790(49,3)$ \\
\hline
\end{tabular}

Profil responden menunjukkan proporsi pada jenis perempuan, tingkat pendidikan $\leq$ SMP, tidak merokok, dan tidak melakukan latihan fisik lebih banyak secara bermakna. Jumlah yang mengkonsumsi alkohol sangat rendah proporsinya yaitu 8 orang atau hanya $0,5 \%$ demikian juga dengan komorbiditas terkait penyakit kardiovaskuler relatif rendah 7,1\%. Komorbiditas meliputi diabetes mellitus, hiperkolesterolemia, asam urat, stroke, gagal ginjal kronis, hipotensi, dan penyakit jantung lain yang disebut sebagai lemah jantung oleh responden (Tabel 2). 
Tabel 2. Profil Responden Berdasarkan Nilai Kategori dari Penelitian the Rule of Halves

\begin{tabular}{lcc}
\hline \multicolumn{1}{c}{ Variabel } & Jumlah & Persentase (\%) \\
\hline Jenis Kelamin* & & \\
Laki-laki & 623 & 38,9 \\
$\quad$ Perempuan & 979 & 61,1 \\
Pendidikan* & & \\
SSMP & 1093 & 68,2 \\
> SMP & 509 & 31,8 \\
Merokok* & & 31,5 \\
Ya & 505 & 68,5 \\
Tidak & 1097 & 71,2 \\
Latihan Fisik* & & 28,8 \\
Tidak & 1140 & 0,5 \\
Ya & 462 & 7,1 \\
Konsumsi alkohol & 8 & \\
Komorbiditas & 114 & \\
\hline Komorbiditas terkait hiperten
\end{tabular}

Komorbiditas terkait hipertensi/jantung terdiri dari: DM 40; hiperkolesterolemia 20; asam urat 19 ; pasca stroke 5; ginjal kronis 2; hipotensi 1; penyakit jantung lain-lain 20.

* nilai-p<0,05 dengan one sample binomial test

Umur rata-rata responden sedikit di bawah 55 tahun tetapi responden yang hipertensi secara bermakna lebih tua dibanding yang tidak hipertensi. Faktor umur merupakan faktor penting dalam prevalensi hipertensi, terbukti juga pada penelitian ini. Pasien hipertensi selain lebih tua juga memiliki BMI yang lebih besar, serta tekanan darah sistolik dan diastolik yang lebih tinggi bermakna berdasarkan uji-T (Tabel 3).

Tabel 3. Perbedaan Profil Responden dengan Hipertensi dan Tidak Hipertensi

\begin{tabular}{|c|c|c|c|}
\hline Variabel & $\begin{array}{c}\text { Hipertensi } \\
(\geq 140 / 90 \mathrm{mmHg}) \\
\text { Rerata } \pm \text { SD }(\mathrm{n}=790)\end{array}$ & $\begin{array}{l}\text { Tidak Hipertensi } \\
\text { (<140/90mmHg) } \\
\text { Rerata } \pm \text { SD (n=812) }\end{array}$ & $\begin{array}{c}\text { Total subject } \\
\text { Rerata } \pm \text { SD } \\
(\mathbf{n}=1602)\end{array}$ \\
\hline Usia (tahun)* & $57,6 \pm 12,0$ & $51,2 \pm 10,6$ & $54,3 \pm 11,8$ \\
\hline BMI $(\mathrm{kg} / \mathrm{m} 2)^{*}$ & $23,2 \pm 4,4$ & $22,8 \pm 3,9$ & $23,0 \pm 4,2$ \\
\hline TDS (mmHg)* & $159,0 \pm 18,8$ & $124,1 \pm 10,6$ & $141,3 \pm 23,1$ \\
\hline TDD (mmHg)* & $89,8 \pm 12,7$ & $78,0 \pm 8,4$ & $83,8 \pm 12,3$ \\
\hline
\end{tabular}

*Uji-t antara kelompok $\geq 140 / 90 \mathrm{mmHg}$ dan $<140 / 90 \mathrm{mmHg}$ dengan $\mathrm{p}<0,05$.

The rule of halves pada tingkat sadar dan tidak sadar hipertensi dianalisis pada responden hipertensi saja, sedangkan terapi dan tidak terapi dianalisis dari yang sadar hipertensi saja. Untuk tingkat sadar hipertensi dan terapi hipertensi tidak ada perbedaan usia maupun tekanan darah responden. Responden tahap sadar dan menerima terapi lebih besar BMInya $(\mathrm{p}<0,05)$. Pada tahap pengendalian tekanan darah perbedaan bermakna terlihat pada faktor umur dan tentu saja tekanan darah sistolik dan diastolik (Tabel 4). 
Tabel 4. Perbedaan Profil Responden Hipertensi yang Sadar dan Tidak, Terapi dan Tidak Terapi, serta Tekanan Darah Terkendali dan Tidak Terkendali

\begin{tabular}{lcccccc}
\hline \multirow{2}{*}{ Variabel } & \multicolumn{2}{c}{ Sadar Hipertensi } & \multicolumn{2}{c}{ Terapi Hipertensi } & \multicolumn{2}{c}{$\begin{array}{c}\text { Tekanan Darah } \\
\text { Terkendali }\end{array}$} \\
\cline { 2 - 7 } & Ya & Tidak & Ya & Tidak & Ya & Tidak \\
\hline Usia (tahun) & $57,2 \pm 12,0$ & $58,2 \pm 12,0$ & $57,1 \pm 11,3$ & $57,9 \pm 12,1$ & $52,7 \pm 10,1$ & $58,0 \pm 12,0$ \\
BMI (kg/m2) & $23,6 \pm 4,4$ & $22,7 \pm 4,3$ & $23,6 \pm 4,4$ & $22,9 \pm 4,4$ & $23,5 \pm 3,5$ & $23,2 \pm 4,4$ \\
TDS (mmHg) & $159,5 \pm 20,4$ & $158,0 \pm 16,3$ & $160,6 \pm 22,7$ & $157,8 \pm 15,9$ & $131,3 \pm 8,9$ & $161,1 \pm 17,7$ \\
TDD (mmHg) & $89,3 \pm 11,5$ & $89,3 \pm 11,5$ & $90,2 \pm 13,7$ & $89,6 \pm 12,0$ & $81,4 \pm 8,3$ & $90,5 \pm 12,7$ \\
$\begin{array}{l}\text { Uji-t } \\
\text { Kelompok Ya } \\
\text { dan Tidak }\end{array}$ & $\mathrm{p}<0,05$ untuk BMI & $\mathrm{p}<0,05$ untuk BMI & $\begin{array}{c}\mathrm{p}<0,05 \text { untuk umur, } \\
\text { tekanan darah sistolik } \\
\text { dan diastolik }\end{array}$ \\
\hline
\end{tabular}

Distribusi responden berdasarkan the rule of halves, prevalensi responden dengan tekanan darah $\geq 140 / 90 \mathrm{mmHg}$ mendekati $50 \%$ sesuai the rule. Responden yang sadar hipertensi menurut the rule adalah $50 \%$ dari hipertensi atau $25 \%$ dari total responden, temuan lebih baik dari the rule $(29,3 \%)$. Terapi dalam penelitian ini adalah terapi farmakologi hipertensi rutin. Terapi temuan penelitian ini $(19,0 \%)$ juga lebih baik dari the rule yang besarnya $50 \%$ dari $25 \%$ yaitu $12,5 \%$ dari responden total. Responden yang terkendali tekanan darahnya yaitu $3,6 \%$ lebih rendah daripada the rule sebesar $6,25 \%$ dari responden total (Gambar 1).

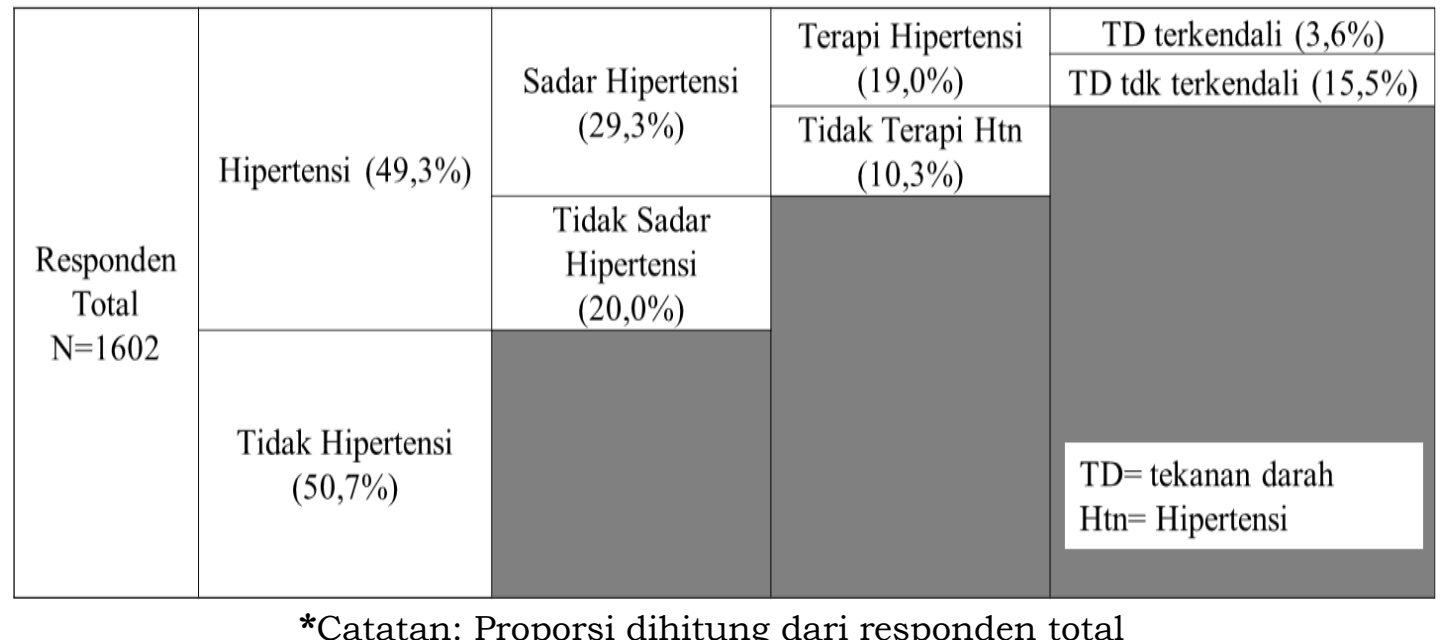

Gambar 1. Profil Responden berdasarkan the Rule of Halves terdiri dari Responden Total, Hipertensi, Sadar Hipertensi, Terapi dan Tekanan Darah Terkendali

Analisis dilanjutkan dengan uji$Z$ untuk membandingkan temuan dengan besaran proporsi $50 \%$ dari the rule. Prevalensi hipertensi dari the rule dan hasil temuan penelitian tidak berbeda bermakna. Pasien yang sadar hipertensi dan menerima terapi hipertensi proporsinya lebih baik secara bermakna dibandingkan dengan the rule, namun demikian proporsi yang berhasil mengendalikan tekanan darah lebih rendah secara bermakna dibandingkan dengan pengendalian hipertensi the rule dengan nilai $\mathrm{p}<0,05$ (Tabel 5) 
Tabel 5. Uji-Z Proporsi Hipertensi, Sadar Hipertensi, Terapi Hipertensi, dan Pengendalian Tekanan Darah (The Rule of Halves)

\begin{tabular}{|c|c|c|c|c|}
\hline Karakteristik & hipertensi & \multicolumn{2}{|c|}{ sadar hipertensi terapi hipertensi } & kendali TD \\
\hline Jumlah & & & & \\
\hline Responden & 790 & 470 & 305 & 58 \\
\hline $\begin{array}{l}\text { Proporsi the } \\
\text { rule of halves } \\
\text { Hasil } \\
\text { observasi }\end{array}$ & $50 \%$ & $50 \%$ & $50 \%$ & $50 \%$ \\
\hline Proporsi 1) & $49,3 \%$ & $\begin{array}{c}59,5 \% \\
(59,5 \%)\end{array}$ & $64,9 \%$ & $19,0 \%$ \\
\hline Proporsi 2) & (n.a.) & & $(38,6 \%)$ & $(7,3 \%)$ \\
\hline $\begin{array}{l}\text { nilai-p } \\
95 \% \mathrm{CI}\end{array}$ & 0,58 & $\mathrm{p}<0,01$ & $\mathrm{p}<0,01$ & $\mathrm{p}<0,01$ \\
\hline $\begin{array}{l}\text { proporsi } \\
\text { pengamatan }\end{array}$ & $46,8-51,8$ & $26,2-32,6$ & $15,6-22,8$ & $1,8-6,3$ \\
\hline
\end{tabular}

Catatan:

TD = tekanan darah; subyek total $n=1602$

Proporsi 1) dihitung dari tingkatan the rule of halves sebelumnya

Proporsi 2) dihitung dari responden yang hipertensi atau TD $\geq 140 / 90 \mathrm{mmHg}$

Nilai-p dianalisis dari hasil observasi proporsi 1).

\section{PEMBAHASAN}

Faktor umur merupakan faktor penting dalam prevalensi hipertensi. Hal ini terbukti juga pada penelitian ini, responden hipertensi secara bermakna lebih tua. Responden hipertensi juga memiliki BMI yang lebih besar. Umur responden lebih tua dan BMI lebih besar, responden tentunya memiliki tekanan darah sistolik/diastolik yang lebih tinggi. Respoden total memiliki rerata umur di bawah 60 tahun, namun rata-rata responden memiliki tekanan darah sistolik di atas $140 \mathrm{mmHg}$ dengan diastolik di bawah 90mmHg. Tekanan darah demikian dikategorikan sebagai isolated systolic hypertension yang lebih umum dialami pada geriatrik dan dengan potensi risiko kardiovaskuler yang tinggi. ${ }^{5}$ Rerata BMI $23 \mathrm{~kg} / \mathrm{m}^{2}$ nilainya berada di perbatasan overweight atau berat badan berlebih. Berdasarkan profil umur, BMI, dan tekanan darah, dapat dikatakan responden relatif berisiko penyakit kardiovaskuler.
Dalam the rule of halves faktor jenis kelamin dapat berpengaruh terhadap hipertensi misalnya pengendalian tekanan darah lebih baik pada perempuan, namun demikian penelitian ini tidak membahas lebih lanjut pengaruh faktor jenis kelamin terhadap hipertensi. ${ }^{15}$ Responden juga teramati lebih banyak yang memiliki tingkat pendidikan formal $\leq$ SMP dan kurang latihan fisik. Kedua faktor merupakan faktor yang meningkatkan prevalensi.6,7 Tidak merokok lebih besar proporsinya dan merupakan faktor yang relatif positif untuk mengurangi prevalensi. Komorbiditas yang ditemukan relatif rendah, tetapi besar kemungkinan jumlah tersebut bersifat semu karena banyak pasien yang tidak sadar hipertensi kemungkinan besar juga tidak menyadari adanya penyakit kardiovaskuler lainnya.

Faktor konsumsi alkohol merupakan variabel penting untuk mengendalikan hipertensi menurut Dietrary Approach to Stop Hypertension 
(DASH). ${ }^{4}$ Jumlah responden yang mengkonsumsi alkohol hanya 8 orang, kurang memadai jumlahnya sehingga variabel ini tidak dibahas lebih lanjut. Rendahnya proporsi konsumsi alkohol kemungkinan terkait dengan larangan alkohol pada sebagian besar masyarakat Indonesia. Rendahnya faktor konsumsi alkohol merupakan faktor yang menguntungkan untuk prevalensi hipertensi.

Prevalensi temuan penelitian ini berbeda tidak bermakna dengan the rule (uji- $Z \mathrm{p}>0,05$ ), namun demikian prevalensi responden lebih tinggi dari prevalensi Riskesdas tahun 2007. ${ }^{1} \mathrm{Hal}$ ini disebabkan umur responden penelitian mulai dari 40 tahun sedangkan Riskesdas 2007 dari populasi dewasa.

Responden yang sadar mengalami hipertensi $(29,3 \%)$ lebih baik dari the rule (uji- $Z \mathrm{p}<0,05$ ), namun dari segi klinis proporsi sadar hipertensi yang demikian belum memadai karena yang tidak sadar cukup besar. Tidak sadar berarti juga responden terlambat melakukan diagnosis terhadap penyakit kardiovaskuler dan mendapatkan intervensi terhadap hipertensi baik secara non-farmakologi maupun farmakologi. Hal ini tentunya akan meningkatkan risiko kardiovaskuler responden. Terapi responden yang ditemukan pada penelitian ini $(19,0 \%)$ juga lebih baik dari the rule (uji- $\mathrm{Z} \mathrm{p}<$ 0,05), meskipun relatif lebih tinggi yang menerima terapi hipertensi, proporsi tersebut secara klinis sangat jauh dari memadai.

Proporsi responden yang terkendali tekanan darahnya sangat rendah baik dibandingkan dengan the rule (uji- $Z \mathrm{p}<0,05$ ) ataupun dengan studi di luar negeri baik di negara maju maupun negara berkembang seperti Indonesia. ${ }^{10,11,12}$ Responden dengan pengendalian tekanan darah dianalisis di antara responden yang menerima terapi secara rutin berdasarkan pengakuan responden.
Pengendalian tekanan darah dipengaruhi oleh multi-faktor, misalnya perilaku responden meliputi persepsi sehat responden dan ketaatan minum obat; sistem kesehatan yang berlaku misalnya faktor pendanaan; dan intervensi oleh tenaga kesehatan misalnya pemilihan jenis obat, kecukupan item dan dosis obat hipertensi. ${ }^{16}$ Penelitian ini belum meneliti faktor-faktor tersebut. Belum ada data tingkat ketaatan minum obat, pilihan obat, dan kecukupan terapi jumlah item dan dosis yang diterima responden sehingga sulit dilakukan evaluasi terhadap rendahnya tingkat pengendalian tekanan darah yang ditemukan pada penelitian ini. Penelitian lebih lanjut diperlukan untuk memastikan faktor penyebab rendahnya proporsi yang terkendali tekanan darahnya.

Penelitian cross-sectional ini memiliki keterbatasan karena penetapan tekanan darah responden hanya dilakukan pada satu waktu meskipun pengukuran dilakukan duplo dan sesuai SOP. Metode cluster random sampling baru mencapai $48,1 \%$ dari populasi 8 dusun, namun demikian jumlah sampel $(\mathrm{N}=1602)$ sudah memenuhi ketentuan jumlah subyek minimal. Data faktor terapi rutin diperoleh dari wawancara, kebenaran data sangat dipengaruhi oleh keterbukaan responden. Data terapi rutin sebaiknya disertai dengan meminta responden menunjukkan obat yang sedang dikonsumsi.

\section{KESIMPULAN}

Penelitian the rule of halves hipertensi responden di 8 dusun bagian selatan Sleman Yogyakarta $(\mathrm{N}=$ 1602) dapat disimpulkan mempunyai proporsi prevalensi, sadar hipertensi, terapi hipertensi, dan pengendalian tekanan darah berturut-turut sebesar $49,3 \% ; 29,3 \% ; \quad 19,0 \%$; dan $3,6 \%$. Prevalensi hasil temuan tidak berbeda ( $p>0,05)$; kesadaran dan terapi lebih 
tinggi; sedangkan pengendalian lebih rendah bermakna dengan proporsi pada the rule of halves $(\mathrm{p}<0,05)$.

\section{REFERENSI}

1. Rahajeng E, Tuminah S. Prevalensi Hipertensi dan Determinannya di Indonesia, Maj Kedokteran Indonesia; 59:12.

2. Depkes RI (Indonesian Ministry of Health). Hipertensi Faktor Risiko Utama Penyakit Kardiovaskular. 2010.

3. WHO. Global Health Risks, Mortality and burden of disease attributable to selected major risks, WHO Geneva; 2009.

4. Chobanian AV., Bakris GL, Black HR, et al. Seventh Report of the Joint National Committee on Prevention, Detection, Evaluation, and Treatment of High Blood Pressure. Hypertension. 2003;42:12 06-1252.

5. Mancia G, Fargard R, Narkiewicz K, et al. The Task Force for the management of arterial hypertension of the European Society of Hypertension (ESH) and of the European Society of Cardiology (ESC). 2013 ESH/ESC Guidelines for the management of arterial hypertension. J Hypertens ;2013;31:1281-1357.

6. Bowman TS, Gaziano M, Buring $\mathrm{JE}$, et al. A Prospective Study of Cigarette Smoking and Risk of Incident Hypertension in Women. $J$ Am Coll Cardiol; 2007;50(21):208592. doi:10.1016/j.jacc.2007.08.017.

7. Regidor E, Gutie'rrez-Fisac JL, Banegas JR, et al. Association of adult socioeconomic position with hypertension in older people. $J$ Epidemiol Community Health 2006;60:74-80. doi: 10.1136/jech. 2005.038331 .
8. Atmarita, Nutrition Problems in Indonesia, the Article for An Integrated International Seminar and Workshop on Lifestyle Related Diseases. http://gizi.depkes. go.id/download/ nutrition problem in Indonesia.pdf;2005 : Accessed on 5 April 2013.

9. Hart JT. Rule of Halves: Implications of Increasing Diagnosis and Reducing Dropout for Future Workload and Prescribing Costs in Primary Care. Br J Gen Prac; 1992;42:116-9.

10. Scheltens T, Bots ML, Numans $\mathrm{ME}$, et al. Awareness, treatment and control of hypertension: the 'rule of halves' in an era of riskbased treatment of hypertension. $J$ Hum Hypertens. 2007;21(2):99106.doi:10.1038/si.ihh.100212

11. Rao V, Daniel A. Application of the "Rule of Halves" for Hypertension as an Assessment Tool in an Urban Slum at Davangere. Nat $J$ Comm Med 2014;5(3):333-336.

12. Wyatt SB, Akylbekova EL, Wofford MR, et al. Prevalence, Awareness, Treatment, and Control of Hypertension in the Jackson Heart Study. Hypertension 2008;51:650-6.

doi.1161/HYPERTENSIONAHA. 107 10008.

13. Dahlan S. Besar Sampel dan Cara Pengambilan Sampel. Salemba Medika. Jkt;2013 ; p.41.

14. Daugherty SL, Masoudi FA, Ellis $\mathrm{JL}$, et al. Age Dependent Gender Differences in Hypertension. http: / /www.ncbi.nlm.nih.gov/pmc /articles/PMC3319751/pdf/nihms 366688.pdf.2011. Accessed on 9 January 2016.

15. Ogedegbe G. Barriers to Optimal Hypertension Control. $J$ Clin Hypertens. 2008;10(8):644-646. 
